Article

\title{
Reducing Social Exclusion in Highly Disadvantaged Districts in Medellín, Colombia, through the Provision of a Cable-Car
}

\author{
Diego Zapata Cordoba ${ }^{1, *}$, John Stanley ${ }^{1}$ and Janet Stanley ${ }^{2}$ \\ ${ }^{1}$ Institute of Transport and Logistic Studies, Faculty of Economics and Business, University of Sydney, NSW 2006, \\ Australia; E-Mails: dzap4701@uni.sydney.edu.au (D.Z.C.), john.stanley@sydney.edu.au (J.S.); Tel.: +57-300-6172885 \\ (D.Z.C.), +61-3-96390728 (J.S.) \\ ${ }^{2}$ Monash Sustainability Institute, Monash University, Clayton, Victoria 3800, Australia; \\ E-Mail: janet.stanley@monash.edu; Tel.: +61-3-99020739; Fax: +61-3-99059348 \\ * Corresponding author
}

Submitted: 26 June 2014 | Accepted: 7 August 2014| Published: 13 October 2014

\begin{abstract}
Recent research has shown that increasing trip making and improving a person's social capital and sense of community is likely to reduce risks of social exclusion, and increase wellbeing. This, and most other related research on social exclusion, has been undertaken in countries with developed economies. This paper examines some of these relationships within a developing economy, where social exclusion is likely to be more widespread, using secondary data. It examines two districts in Medellín, Colombia, which are historically marginalised, with considerable poverty and also suffering from substantial drug-related violence. The focus is on the role of Metrocable, an aerial cable-car public transport system built to improve transport options in the area's steep terrain, in reducing risk of exclusion. The analysis shows that increasing the number of trips is significantly associated with a reduced risk of social exclusion and that increasing social capital is weakly supportive. Metrocable is therefore likely to be successful in reducing exclusion. The model suggests that secondary data can be used to explore relationships between mobility and risk of social exclusion.
\end{abstract}

\section{Keywords}

cable-car; mobility; social capital; social exclusion; trips; well-being

Issue

This article is part of a regular issue of Social Inclusion, edited by Professor Ulf R. Hedetoft (University of Copenhagen, Denmark).

(C) 2014 by the authors; licensee Cogitatio (Lisbon, Portugal). This article is licensed under a Creative Commons Attribution 4.0 International License (CC BY).

\section{Introduction}

The concept of social exclusion describes a situation where a person has reduced capacity to engage fully in society. The current understanding of social exclusion and its relationship with transport and mobility has largely grown from the pioneering research undertaken by the Social Exclusion Unit in the United Kingdom (Social Exclusion Unit, 2003). In contrast, North American research has tended to focus on the mobility limitations of particular groups thought likely to be transport disadvantaged (e.g. older persons) (see, for example, Spinney, Scott, \& Newbold, 2009), although there is a presently growing interest in links between mobility and social exclusion, especially among practitioners of public transport network design.

A body of research in Australia has focused on the links between mobility, risk of social exclusion, and well-being, partly to identify the role that improved provision of public transport might play in reducing risks of exclusion and improving well-being (see for example Stanley, Stanley, \& Hensher, 2012). The Australian research was able to draw on primary customised data, collected in extensive personal interviews with a 
large number of respondents (over 1000). The size of this original data collection raises questions in this paper about the repeatability of the research methodology, given the high cost of such primary data collection, and whether there is other data which may be suitable for a similar analysis. Also, there has been little published research about connections between mobility and risk of social exclusion in a developing country context, where a much greater proportion of the population is likely to experience social exclusion. This paper also seeks to tackle this knowledge gap. It does so by examining links between mobility, social exclusion and well-being in the circumstances of an emerging economy, Medellín, Colombia, using secondary data to mirror the primary data used by Stanley et al. (2011a), Stanley, Hensher, Stanley, \& Vella-Brodrick (2011b) and Stanley et al. (2012).

Medellín, Colombia's second largest city, has an innovative cable-car public transport system, Metrocable, which has attracted international attention as a governmental response to the exclusion problems of a historically marginalised area. In this area, complex social issues are exacerbated by steep terrain, which makes the provision of mobility infrastructure difficult. To date, however, there has been no assessment of whether Metrocable has been effective in reducing risk of social exclusion in its area of influence.

Section 2 of this paper reviews the main conceptual contributions in social exclusion and its relationship with mobility. Section 3 presents the frameworks used to measure social exclusion and the model structure adopted in this paper. Section 4 introduces the main characteristics of Medellín's cable car system and the economic and social research undergone in its area of influence. Section 5 describes the data sources utilized in this study and its treatment as to comply with the dimensions of social exclusion and the variables of the model. The paper concludes with a summary of the results and a short discussion on the opportunities that the Metrocable system offers as a public transport alternative, as well as commenting on the viability of using existing data sources to measure the impact of mobility on social exclusion.

\section{Social Exclusion and Mobility}

The concept of social exclusion has gradually gained relevance in social policy discussions, traditionally dominated by the notions of poverty and income. Sen (2000) recognises that the concept of social exclusion encompasses a broad range of socio-economic problems beyond low income. He distinguishes between two ways in which social exclusion can prompt capability deprivation. Firstly, just being excluded in itself can be of intrinsic importance. Sen gives the example of where a person may not be able to relate to others and take part in the life of a community. Instrumental social exclusion refers to a situation which may not be exclusionary in itself but can lead to reduced capabilities through their causal consequences. The absence of transport to enable personal mobility could be an example of this.

The (now disbanded) Social Exclusion Unit in the United Kingdom (2003) focussed attention on the relationship between social exclusion and mobility, finding that negative impacts produced by transport have a larger impact on lower socio-economic communities, such as higher levels of traffic accidents, pollution and congestion. That research also showed that the groups of people experiencing mobility problems tended to be the same groups defined as in greater risk of social exclusion.

Mobility-related social exclusion is defined as the process by which, due to the deficient or non-existent means to travel, people are restricted from participating in the economic, political and social life of the community, as consequence of limited accessibility to opportunities (Kenyon, Lyons, \& Rafferty, 2002). An individual experiences mobility-related social exclusion when their transport expenditure-expressed in terms of time and cost-or available transport opportunities prevent them from maintaining the set of contacts and facilities they require.

Noted in 2008 but still relevant today, the relationship between mobility and social exclusion in general requires considerably more work, and the issue on emerging economies remains relatively unexplored (Stanley \& Lucas, 2008). However, work by Jaramillo, Lizárraga, \& Grindlay (2012) suggests that social exclusion is widely present in Latin America and aggravated by deficient public transport. It could be hypothesised that a large percentage of the population living in developing countries experience mobility-related social exclusion due to the size of the informal transport sector, a symptom of unfulfilled mobility needs (Stanley \& Mulley, 2010).

Brand and Davila (2011) note that the mobility of underprivileged people in developing societies, as expressed in their number of trips, is significantly constrained by low, irregular incomes. This, in turn, determines their opportunities to improve their quality of life. As the cost of public transport can represent a relatively high percentage of a household's income, their mobility is at risk of being restricted to essential activities, limiting their participation in urban life and narrowing their work, education, leisure, social and political expectations. Restricted mobility is therefore likely to transform geographic marginalisation into social exclusion.

The absence of an assessment of the value of reducing social exclusion through greatly improved public transport services poses a significant setback, as it confines the argument on the importance of mobility in reducing social exclusion to the qualitative ground and therefore less able to be successfully integrated in project appraisals and evaluations (Stanley et al., 2011a). 


\section{Measuring Social Exclusion}

Burchardt, LeGrand and Piachaud (2002), at the London School of Economics, developed a four-dimensional framework for the measurement of social exclusion. Even though there may be interaction between these dimensions, each one represents an outcome in its own and is likely to contribute to a risk of social exclusion. Building on this work, Stanley et al. (2011a) developed a modified five dimensional framework for their Australian research, shown in Table 1 together with the definition of the indicator and a threshold point. These modifications were made to give a wider definition of political activity than 'vote/did not vote' used by Burchardt et al. (2002) and to add an additional dimension in order to separate social support and participation, the Australian researchers believing them to be different concepts. In their work, the risk of social exclusion is assumed to increase with the number of unmet thresholds, each dimension having equal weight.

Stanley et al. (2011b) hypothesised a model about the relationship between the risk of social exclusion and subjective well-being and a range of other possible influencing factors thought on a priori grounds to be causally linked with these conditions. Subjective wellbeing was measured using the Personal Well-being Index, comprising eight domains on quality of life (International Wellbeing Group, 2006).

On estimating the model (see Figure 1) they found that the risk of social exclusion decreases if a person has higher levels of social capital. This was defined as a range of networks, as the trust and reciprocity components also included in Putnam's definition of social capital (1995) did not prove important in prior testing. The person also needs to be relatively mobile (as measured by number of trips taken), extraverted in personality (not defined here as the variable is not subject to policy intervention and is of interest only) and does not have a low income.

Subjective well-being improves if the individual has a low risk of social exclusion, as well as significant levels of environmental mastery, positive relations with others and self-acceptance-domains drawn from Ryff's (1989) 44 item scale of psychological well-being. A sense of community was also significant for wellbeing, as measured by: 'I think my neighbourhood is a good place for me to live', an item in the 12 point Sense of Community Scale (Obst \& White, 2004) which showed good representation with all items when tested. Age has positive relationship with well-being, again being of interest only in a policy sense. The parameters of the model were estimated for Melbourne and regional Victoria, Australia, using a three stage least squares method. The model structure forms the general basis for the approach that is developed in the current paper.

Table 1. Australian Indicators of social exclusion.

\begin{tabular}{ll}
\hline Dimension & Indicator and Threshold \\
\hline $\begin{array}{l}\text { Household } \\
\text { income }\end{array}$ & $\begin{array}{l}\text { Less than a threshold of \$A500 gross } \\
\text { per week } \\
\text { status }\end{array}$ \\
Political & $\begin{array}{l}\text { Neither employed, retired, in education } \\
\text { or training, looking after family, nor } \\
\text { undertaking voluntary work }\end{array}$ \\
activity & $\begin{array}{l}\text { Did not contribute to/participate in a } \\
\text { government political party, campaign, } \\
\text { or action group to improve } \\
\text { social/environmental conditions, to a } \\
\text { local community committee/group in } \\
\text { the past 12 months }\end{array}$ \\
Social support & $\begin{array}{l}\text { Not able to get help if needed from } \\
\text { close or extended family, friends or } \\
\text { neighbours }\end{array}$ \\
Participation & $\begin{array}{l}\text { Did not attend a library, sport } \\
\text { (participant or spectator), hobby, or arts } \\
\text { event in the past month }\end{array}$
\end{tabular}

Source: Stanley et al. (2011a, p. 201).

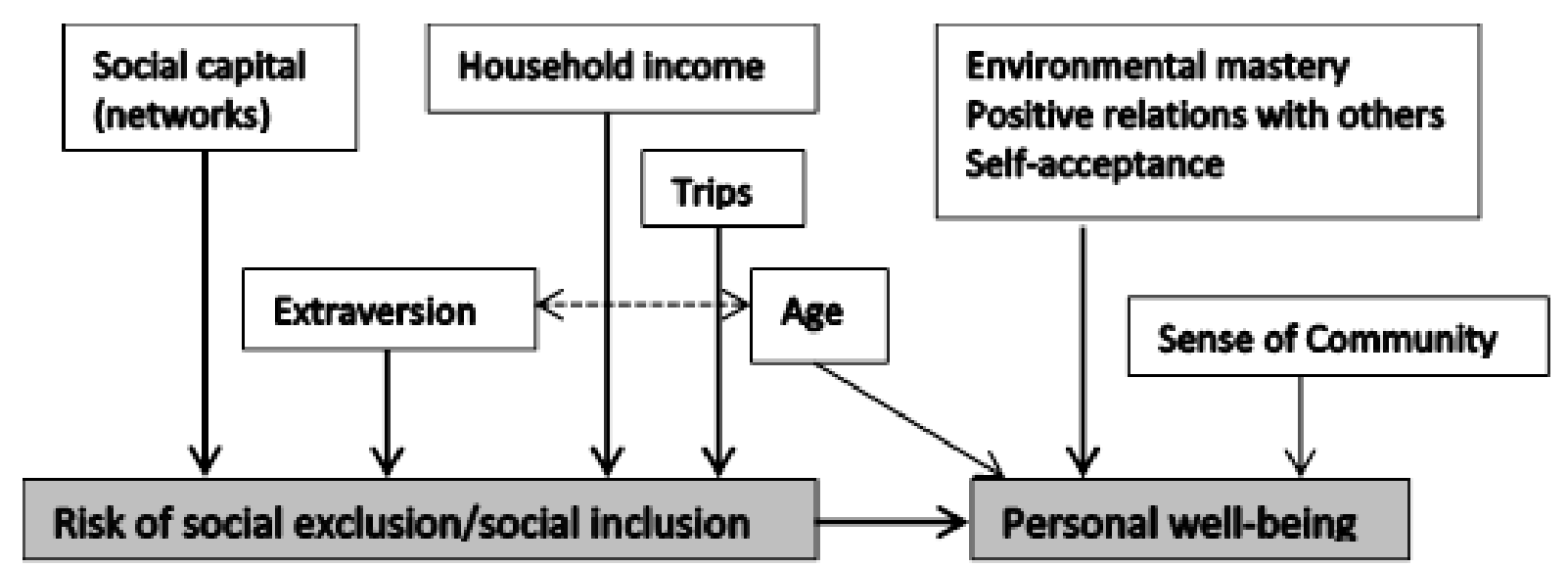

Figure 1. Mobility, social exclusion and well-being: hypothesized relationships (based on Stanley et al., 2011a) 


\section{Medellín's Cable-Car System and Its Economic and User Impact}

Medellín has experienced a local urban transformation following the innovative application of ski-slope technology to urban transport problems, having developed (by 2004) the world's first modern, urban aerial cablecar public transport system. Metrocable, as the system is known, is a financially viable and highly visible response to the exclusion problems experienced by a highly violent, historically marginalised and poverty stricken area, isolated from the rest of the city by an intricate high-gradient topography, that has contributed to the perpetuation of such issues. Leibler and Brand (2012) argue that the objective of Metrocable, and subsequent urban revitalisation projects or $\mathrm{PUI}^{1}$, was to reduce the social and spatial exclusion of Popular (District 1) and Santa Cruz (District 2), being used as an axis to redefine the territory by turning those districts into attractive spaces for leisure, while providing an alternative transport mode for daily commuters and enabling the penetration of key services. The main characteristics of Metrocable Line K, the first of two such lines, are presented in Table 2.

Table 2. Metrocable Line K: Basic Characteristics.

\begin{tabular}{ll}
\hline Launch date & August 2004 \\
\hline Construction time & 14 months \\
Length & 2.072 Metres \\
Gradient & 399 Metres \\
Average Line Slope & $20 \%$ \\
Maximum Slope & $49 \%$ \\
Commercial speed & $18 \mathrm{~km} / \mathrm{h}$ \\
Number of pylons & 20 \\
Number of stations & 4 (including metro station) \\
Number of cabins & 93 \\
Distance between cabins & 60 Metres \\
Capacity of cabin & 10 people \\
Installed capacity & 3000 passengers/hour \\
Frequency & 12 seconds \\
Fare charged & US\$0,91 per trip* (average 2013 \\
& exchange rate) \\
Estimated investment & US\$24 million (average 2003 \\
& exchange rate) \\
Cost per kilometre & US\$11.6 million (average 2003 \\
Sources of finance & exchange rate) \\
& Municipality: $55 \%$ \\
\hline Source: Metro company: 45\%
\end{tabular}

Source: Metro de Medellín, 2004. * Fare for Civica cardholder equivalent to COP 1.700 (Colombian Pesos) valid from $2^{\text {nd }}$ January 2014. Alternative trip fares for frequent traveller (US\$0,88), students (US\$0,71), elderly (US\$0,84), reduced mobility people (US\$0,67), and single trip without Civica card (US\$1,02).

The area where Line $\mathrm{K}$ is located was developed

${ }^{1}$ An acronym in Spanish for Integrated Urban Projects. through processes of land invasion and informal settlements for over five decades, on difficult, steep terrain, not projected to be used for urban expansion, much less to hold densities above 30,000 inhabitants per square kilometre. These characteristics limit the alternatives that could be deployed to improve mobility in the area, as road and rail improvements would be extremely costly, and in the case of train, probably impossible to deliver. This is despite the fact that Metrocable has a relatively low capacity, largely exceeded by its latent demand (Sarmiento, Córdoba, Mejía, \& Agudelo, 2012).

Although road building would be extremely costly and disruptive in this setting, a one lane arterial road might provide carrying capacity of up to about 1500 vehicles per hour in ideal circumstances, which in turn would require an average vehicle occupancy rate of two people to match the Metrocable capacity. Cao and Sano $(2012)^{2}$ estimated the number of motorcycle equivalent units (MEU) considering the influences of velocity, physical size of the vehicle and surrounding motorcycles in their methodology; their results denote that the MEU of a car is 3.4, therefore, a one lane arterial road would carry up to 5,100 motorcycles per hour, which would exceed the current capacity of Metrocable Line K. However, this alternative would increase accident numbers substantially. The number of traffic incidents involving a motorcycle increased from 17,940 in 2009 to 25,860 in 2012, with an additional 61 pedestrian casualties associated with motorcycles ${ }^{3}$ in the city (Alcaldía de Medellín, 2013b).

Figure 2 shows the popularity of the Metrocable service, with large crowds at peak hour. The substantial waiting times implied in Figure 2 suggests the users are likely to have low time values, as noted by Sarmiento et al. (2012), or perhaps no choice, implying low incomes.

Metrocable Line $\mathrm{K}$ starts in Acevedo station, on Metro Line A, and goes through the middle of the Popular and Santa Cruz districts, until reaching Santo Domingo station, 399 metres above Acevedo station. The configuration of the system is illustrated in Figure 3.

The Popular and Santa Cruz districts have different characteristics, due to their geographic location and historic development patterns. Santa Cruz is located at the base of the hill and has a gentle slope and an established urban network. The neighbourhoods in this district emerged over fifty years ago, with a group of developers illicitly trading property lots that, at the time, had no access to domiciliary services. Popular is located at the upper part of the hill and is configured by abrupt slopes. Its expansion followed a process of land invasion started in the 1970s, which produced a substandard urban network and a larger number of dwellings in high-risk of slipping areas (Coupé, 2012).

\footnotetext{
2 Estimates on urban roads in Hanoi, Vietnam.

3 Just $6.7 \%$ of all the trips in Medellin during 2012 were made on a motorcycle.
} 


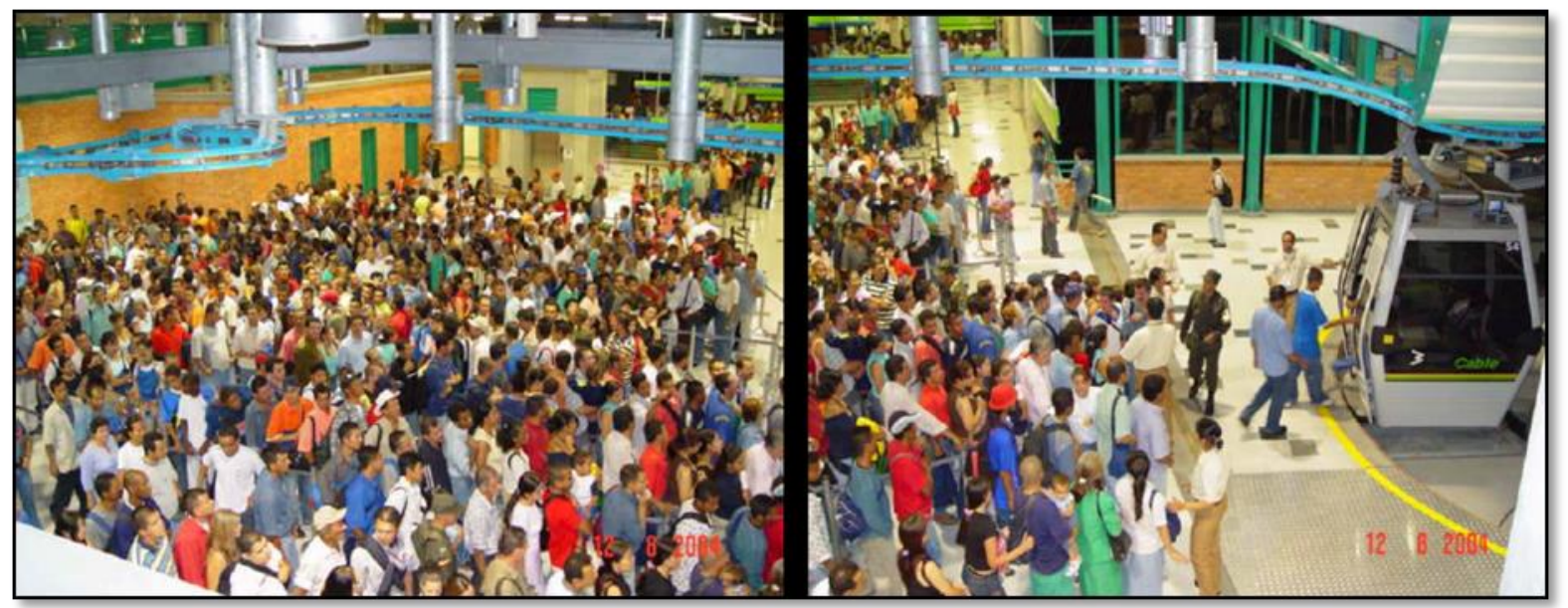

Figure 2. Peak hour queues at Metrocable stations. Source: Metro de Medellín (2004).

The engagement of local institutions with the local community has been a major feature in the implementation of Metrocable. Coupé, Brand and Dávila (2012) comment on three distinctive elements leading to its success: the political leadership and commitment of three consecutive administrations; the function and structure of Medellín public companies (Empresa de Transporte Masivo del Valle de Aburra ${ }^{4}$ and $E P M^{5}$ ); and the implementation of participative planning and budgeting as management instruments to strengthen the relationship between state and society and foster the creation of social capital.

Brand and Davila (2011) emphasize two important features that enhanced the impact of Metrocable Line $\mathrm{K}$ : first, the reciprocal needs of improving the accessibility of the sector dwellers to the Metro system, and exploiting the underused capacity of such system; and second, the transport intervention was followed by other urban revitalisation projects in the area. Metrocable Line $\mathrm{K}$ was used as an axis to upgrade educational, housing, cultural and public space infrastructure ${ }^{6}$. These integral interventions, subsequently deployed in other underprivileged sectors of the city, were branded as social urbanism, a concept that embodies the intent of the municipality to lead a:

profound social transformation and a new social contract in the more deprived and violent sectors of the city, on the bases of spaces for citizenship and settings for democracy and peaceful co-existence (Brand \& Davila, 2011, p. 656).

Complexity (Leibler \& Brand, 2012) and limited data on

\footnotetext{
${ }^{4}$ Metro Company responsible for the operation of the Metro system including Metrocable and Metroplus (BRT).

${ }^{5}$ Medellin Public Utilities Companies, involved in the provision of domiciliary services, hydroelectric power generation and funding of public projects.

${ }^{6}$ The urban interventions in the area in the subsequent four years accounted for seven times the cost of the Line $\mathrm{K}$.
}

the area's informal sector (Brand \& Davila, 2011) are major difficulties in assessing the economic impact of Metrocable and the subsequent interventions. Coupé and Cardona (2012) found that economic activity had increased significantly around the Line $\mathrm{K}$ infrastructure, highlighting the positive impact of positioning Cedezo (the Zone Enterprise Development Centre) near Santo Domingo Station. Nevertheless, in terms of officially measured employment, the proportion of employed household heads remained almost unaltered between 2004 and 2009 for both Popular and Santa Cruz districts. Income, particularly for male household heads, increased significantly during the period as a percentage of the Legal Monthly Minimum Wage (LMMW) and moderately in relationship to the city average (Coupé \& Cardona, 2012). Table 3 illustrates the changes for both districts by gender and compared to Medellín as a whole.

The generation of new business is strongly linked to the creation of new small family stores, located within dwellings, which offer a limited range of daily basics to the local population (called Tiendas de Barrio). The owner is usually also the manager and assistance comes from an unpaid member of the family (not officially measured). Nonetheless such opportunities are limited, due to the skills of the manager and the small trade volume (Coupé \& Cardona, 2012).

The analysis of the area's property market is particularly complex due to the prevalent informality. Fieldwork by Tobón Molina (2012), in the area around Andalucia Station (District 2) gathered data on the variations in property values on the informal market for the years 2002, 2007 and 2011. The study showed a significant variation between 2007 and 2011, when the increase of the value per square metre was $53.18 \%$ and $54.24 \%$ for commercial and residential use respectively. These results contrast with an increase of only $18 \%$ city-wide recorded by the Lonja de Propiedad Raiz de Medellin ${ }^{7}$.

\footnotetext{
${ }^{7}$ Medellín Real State Auction.
} 


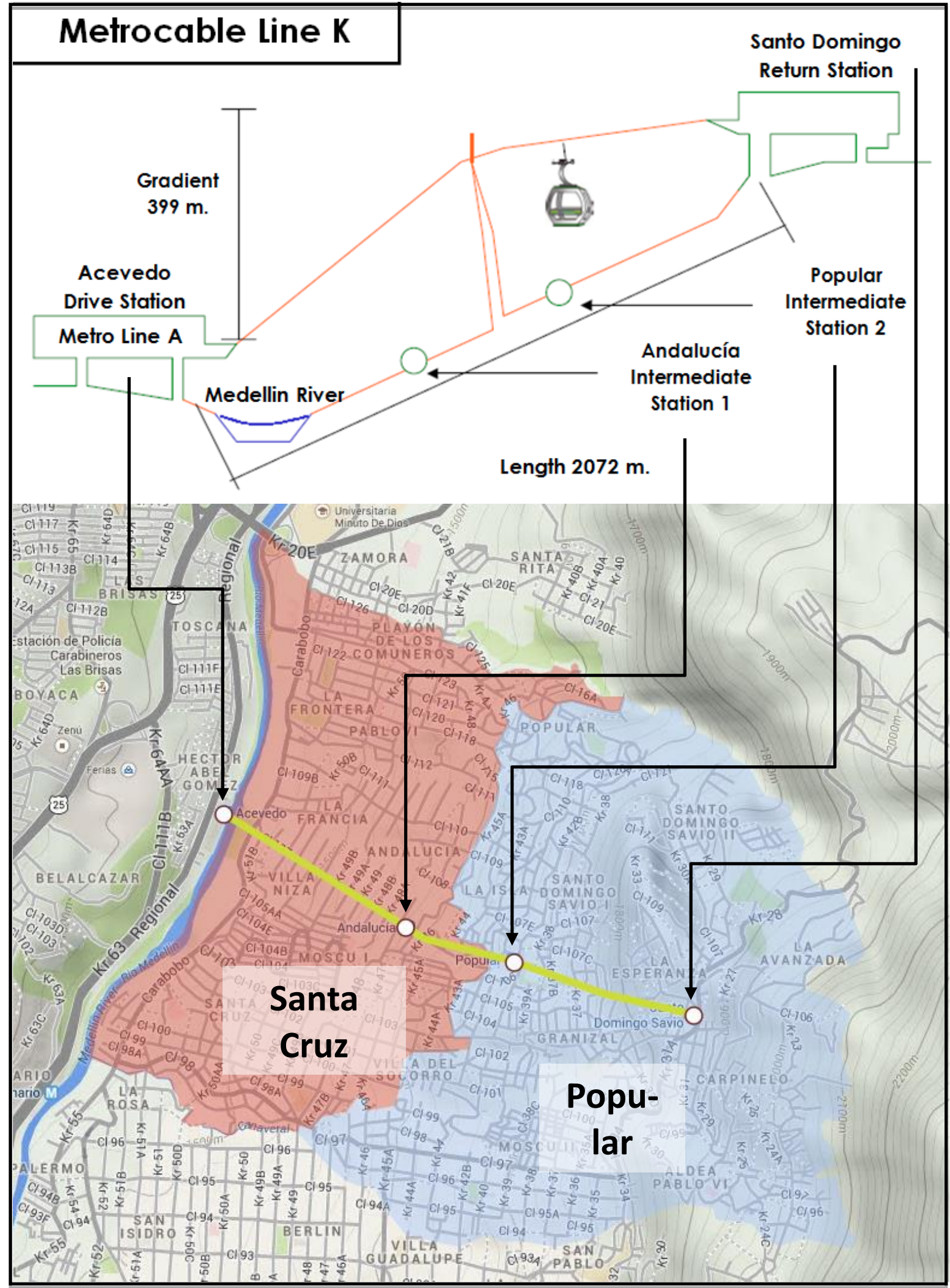

Figure 3. Diagram and Location of Metrocable Line K. Source: Metro de Medellín, 2004. 
Table 3. Average salary of household head per district 2004-2009.

\begin{tabular}{|c|c|c|c|c|c|c|}
\hline \multirow{2}{*}{ Household Head } & \multicolumn{3}{|c|}{$\begin{array}{l}2004 \\
\text { Legal Monthly Minimum Wage US\$201 }\end{array}$} & \multicolumn{3}{|c|}{$\begin{array}{c}2009 \\
\text { Legal Monthly Minimum Wage US\$279 }\end{array}$} \\
\hline & Popular & Santa Cruz & $\begin{array}{l}\text { Medellín } \\
\text { Average }\end{array}$ & Popular & Santa Cruz & $\begin{array}{l}\text { Medellín } \\
\text { Average }\end{array}$ \\
\hline Male & 141 & 142 & 248 & 303 & 310 & 493 \\
\hline Compared against LMMW & $70 \%$ & $71 \%$ & $123 \%$ & $109 \%$ & $111 \%$ & $177 \%$ \\
\hline Compared against Medellín & $57 \%$ & $47 \%$ & - & $61 \%$ & $63 \%$ & - \\
\hline Female & 108 & 110 & 191 & 266 & 269 & 455 \\
\hline Compared against LMMW & $54 \%$ & $55 \%$ & $95 \%$ & $95 \%$ & $96 \%$ & $163 \%$ \\
\hline Compared against Medellín & $57 \%$ & $58 \%$ & - & $58 \%$ & $59 \%$ & - \\
\hline
\end{tabular}

Source: Coupé and Cardona (2012), p. 84.

Leibler and Brand (2012) argue that the Metrocable project in Districts 1 and 2 has benefited only the most proximate locations to the new infrastructure, with the topographic characteristics of the area being the main constraining factor for a wider impact. Thus, even though Line $K$ goes through the geographic middle of Districts 1 and 2, the stations remain inaccessible to the inhabitants of the neighbourhoods located on the opposite side of the hill, and at the southern end of each district. Work by Arango Gómez, Velásquez Torres and Bocarejo Suescún (2011) on accessibility changes in three neighbourhoods in District 1 between 2000 and 2005 corroborate the findings of Leibler and Brand (2012).

Agudelo, Mejía, Sarmiento and Córdoba (2012) identified user perceptions of Metrocable. They found that walking for more than 20 minutes is a common practice if it leads to monetary savings. On security, the view is that Metrocable attracted increased police presence and vigilance to the area. In terms of comfort, the main user concern is long queues to access the gondolas during peak hours. People reluctantly accept the restrictions imposed on food within the vehicles.

\section{Data Sources and Application}

As noted in Section 2, one of the underlying reasons for the present paper has been to test the use of secondary data to replicate the modelling findings of Stanley et al. (2011a, 2011b), where their modelling used primary data for independent variables in models to predict risk of social exclusion. Thus, from Figure 1, proxy type (secondary data sourced) variables are required for social capital, household income, trip rates, age and sense of community, which will be aggregate (area based) data, rather than the disaggregated survey data gathered by Stanley and colleagues. Personality data and data on psychological well-being are not available at that level. Data on the dependent variables, five social exclusion risk factors and subjective well-being, are also required, which will again be at area level rather than individual level.

The quality of life survey undertaken annually by the Medellín Mayor's Office (Alcaldía de Medellín), across the 16 districts and 5 townships that form the city, was the main source of data for this research. The survey monitors and measures the socioeconomic conditions of Medellín inhabitants in six dimensions: population, dwellings, education, economic activity, health and social security, and citizen's perceptions, with each dimension subsequently divided in several sections and indicators.

Responses in the quality of life survey were commonly made on a 5-point Likert scale, ranging from very low to very high, or from very dissatisfied to very satisfied according to the nature of the question. A small set of responses was made on a 3-point scale, such as for neighbourhood security, where it aimed to measure a variation and if it is perceived as worse, equal or better.

\subsection{Risk of Social Exclusion}

Several indicators from the 2012 Mayor's survey (Alcaldía de Medellín, 2013a) were used as proxies for the five social exclusion risk factors, as set out in Table 1 (household income, employment status, social support, participation and political activity) and their respective thresholds, as closely as possible. Because data measures are not identical between the two studies due to their respective data opportunities, the focus in the present study has been to concentrate on measurement of the relative risk of social exclusion in the Medellín districts, for each of the five indicator variables chosen to reflect risk of exclusion. The indicator variables for each dimension were thus set to quantify the proportion of inhabitants in each district that fail against each threshold. This should enable a relative ranking of the different Districts in Medellín, in terms of risk of social exclusion, which should be sufficient to suggest whether or not Metrocable is targeting the right areas, given the goal of reducing exclusion risk. In concordance with Stanley et al. (2011b), each indicator was equally weighted through a normalisation process, as there is no empirical or logical foundation to do otherwise. The results for each district were expressed as the percentage of inhabitants that did not meet the threshold. Table 4 summarises the thresholds that were set for each dimension, in order to quantify the percentage of failure. 
Table 4. Adapted thresholds for the indicators of social exclusion.

\begin{tabular}{|c|c|}
\hline Dimension & District Threshold \\
\hline Household income & $\begin{array}{l}\text { - If average monthly district income is less than COP } 797.786^{*} \text { : One minus the sum of household heads earn- } \\
\text { ing more than COP } 1,000.000 \text {, with the result subsequently divided by the total number of household heads. } \\
\text { - If average month district income is more than COP } 797.786 \text { : One minus the sum of household heads earn- } \\
\text { ing less than COP } 400.000 \text {, with the result subsequently divided by the total number of household heads. }\end{array}$ \\
\hline Employment status & $\begin{array}{l}\text { The sum of household heads whose main activity during the last month has been working, looking for a } \\
\text { job, studying, in home duties or retired with a pension; divided by total number of household heads. }\end{array}$ \\
\hline Political activity & $\begin{array}{l}\text { The sum of household heads who qualified their interest in politics as 'very little', 'little' and 'indifferent', } \\
\text { divided by the total number of household heads, plus the sum of household heads who qualified their level } \\
\text { of confidence in governmental institutions as 'very bad' and 'bad' divided by the total number of house- } \\
\text { hold heads. The result is subsequently divided by two. }\end{array}$ \\
\hline Social support & $\begin{array}{l}\text { The number of inhabitants who migrated to Medellín by public order reasons-violence-divided by the } \\
\text { total number of inhabitants. }\end{array}$ \\
\hline Participation & $\begin{array}{l}\text { One minus the sum of household heads involved in leisure, recreational and sport activities. The result is } \\
\text { subsequently divided by one plus a factor resulting from the average month expenditure in leisure divided } \\
\text { by the average month district income, times the number of households that spend in leisure divided by the } \\
\text { total number of households. }\end{array}$ \\
\hline
\end{tabular}
Source: Personal adaptation of Stanley et al. (2011a, p. 201), using AMVA Quality of Life Survey Data (Alcaldía de Medellín, 2013b); * The threshold was set on COP 797.786 per month, following the poverty line set by the Colombian Government.

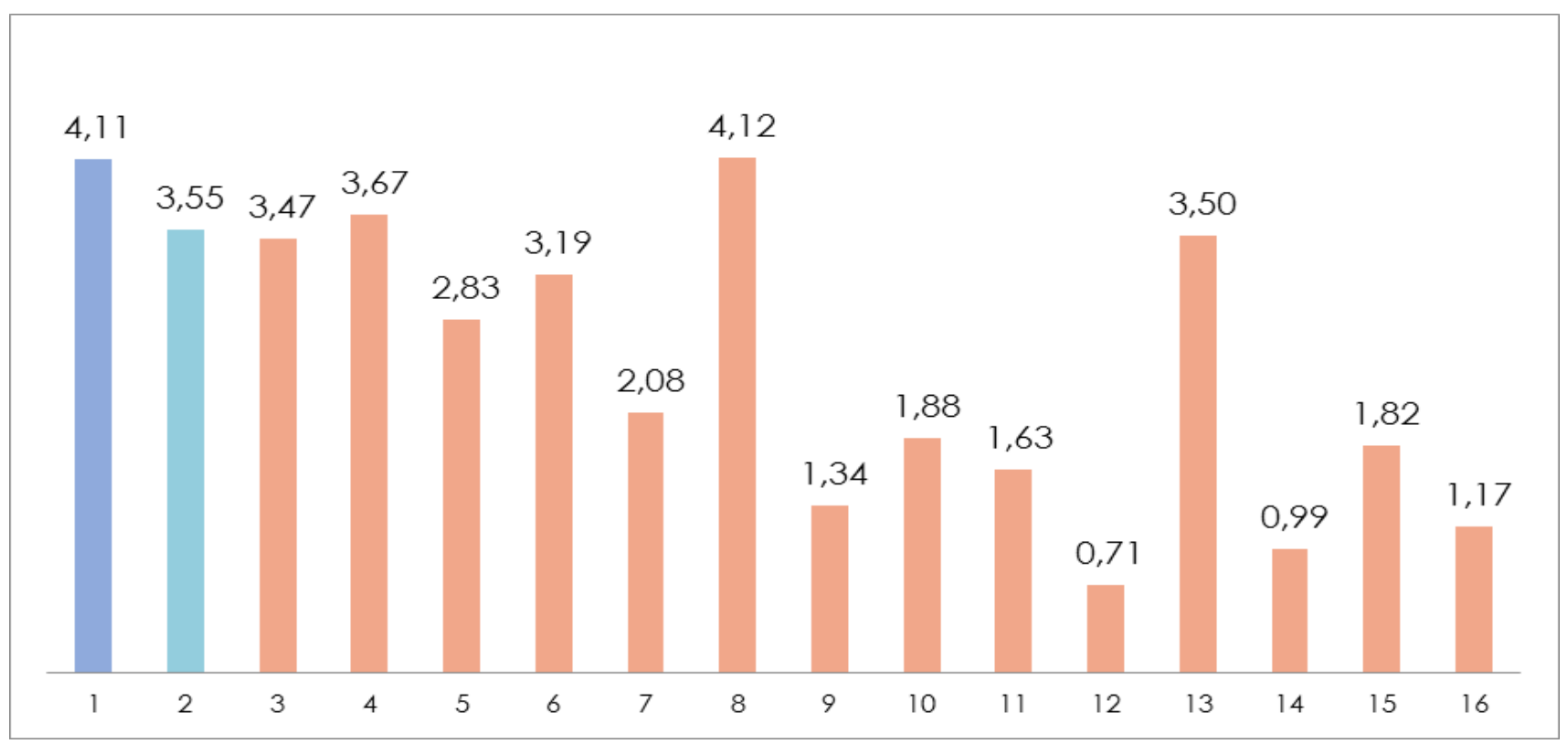

Figure 4. Relative risk of social exclusion per Medellín District, 2012 (author estimates).

Figure 4 shows the relative scores for risk of social exclusion for each of the 16 Districts in Medellín. The most important aspect of the figure is the relative performance of different Districts, which accords with expectations. For example, the Districts of Popular (1) and Santa Cruz (2), which are commonly regarded as very disadvantaged, scored 4.11 and 3.55 in the relative risk of social exclusion respectively, where the maximum possible score is 5 . Risk of social exclusion is thus rated as very high in these districts. Conversely, District 14 , recognized by its financial services and exclusive real estate market, recorded a score of 0.99 , suggesting a low risk of exclusion, as expected.

\subsection{Independent Variables in Model}

Moving now to the independent variables that we are seeking to mirror from the model of Stanley et al. (2011b), thought likely to be significant influences on the risk of social exclusion, the measurement of social capital represented a significant challenge, due to the definitional variability of the concept. Stanley and colleagues defined it as a person's social network plus associated issues of trust and reciprocity (Stanley et al. 2011a, p. 202).

The social capital measure in the model was built using the data collected by the Fundación Antonio Restrepo Barco and the Alcaldía de Medellín (2012) on the Third Social Capital Measurement BARCAS ${ }^{8}$. The size of the sample ( 800 surveys) used by this study was chosen to deliver significant results per districts (Hurtado, García, \& Copete, 2012), which validates the use of this data into our model.

${ }^{8}$ Social Capital Barometer 
The BARCAS methodology calculates three different factors, KSocial, Confie and Fusi, with the KSocial factor being closest to the social capital measure used by Stanley et al. (2011a). KSocial picks up elements of social networks (not related to institutions), trust and reciprocity. The Stanley et al. measure focused on social networks (not related to institutions) and trust, but not reciprocity as this did not prove to be significantly associated with risk of social exclusion in early testing.

The BARCAS model is structured in a multilevel path, on which items and questions (formatted in scale or multiple choice) are constructed into variables, variables aggregated into dimensions and dimensions analysed into factors. It uses the standardised regression weights and the marginal explained variance of each item to explain and build every variable. A similar process is subsequently used as to arrive to the dimensions and factors. The model includes the measurement of 50 variables integrated into 10 different dimensions that affect differently each of the aforementioned factors (Sudarsky, 1999; Hurtado et al., 2012). Table 5 presents the ten dimensions used by the BARCAS methodology.

Table 5. BARCAS dimensions to calculate social capital. BARCAS Dimensions

\section{Social Control}

Hierarchy

Civic Republicanism

Media

Institutional Trust

Political Participation

Civic Participation

Mutuality and Reciprocity

Horizontal Relationships

Information and Transparency

Source: Sudarsky (1999).

Hurtado et al. (2012) found that the dimensions that most critically influence the KSocial factor score in each district were Mutuality and Reciprocity, Horizontal Relationships and Hierarchy, with a positive effect through the variables 'General Solidarity' (Mutuality and Reciprocity), 'Social Activities' both with neighbours and coworkers and 'Horizontal solution of Collective Problems' (Horizontal Relationships) and 'Vertical solution of Collective Problems' (Hierarchy). The variables with a major negative effect on its respective dimensions were 'Opportunism' and 'Atomisation' (Mutuality and Reciprocity), and 'Third Party Enforcement' (Horizontal Relationships). The KSocial scores found for each district by Hurtado et al. (2012) are shown in Figure 5.

Data collected in origin-destination surveys undertaken by Alcaldía de Medellín, Universidad Nacional and Area Metropolitana del Valle de Aburra during the years 2000, 2005 and 2012, was used to identify the variation of the travel patterns of each district between periods, including each district's average number of trips per person/day, mode choice and trip destination (Alcaldía de Medellín, Universidad Nacional, \& Área Metropolitana del Valle de Aburrá, 2001, 2006, 2013). The data used to calculate the average number of trips per person per day for each District, as required for modelling purposes, shows unrealistic figures, as all the Districts registered an average of less than 2 (one-way) trips per day for the three periods of study. The explanation for these low figures is likely to be the partial nature of the trip measure that was implemented: trips of less than five minutes or five blocks were not counted in the survey. If the average density of 7,000 people per square kilometre of the city and high level of the mixed land use in several districts are taken into consideration, it is probable that a significant number of trips were not accounted. Interpretation of the trips variable in the subsequent modeling should thus be in terms of longer trips.

The travel patterns of study Districts 1 and 2 tend to be significantly different to the Medellín average: the main transport mode is walking and the level of usage of the metro system is higher, although declining for District 2. This trend can be explained by an increased number of trips made by motorcycle and also as result of a larger offer of services within the district, derived from improvements in accessibility resulting from the associated urban revitalisation initiatives, which boosted the trips made by walking by 13 percentage points since 2000. Even though the shortest trips are not measured, the main trip destination for measured trips in Districts 1 and 2 is in the same District, suggesting a very high level of trip containment, with District 10 (the downtown) being the second main destination for both areas.

The personal wellbeing element of the Figure 1 model was similar to the Perception of Quality of Life indicator in the Medellín 2012 survey, being based on similar question: How do you qualify the quality of life of the members of your family? The answers ranged from 'very bad' (1) to 'very good' (5).

The Quality of Life surveys from 2004 to 2009 (Alcaldía de Medellín, 2005, 2006, 2007, 2008, 2009, 2010) also provided the data to calculate the average household income in each year, values that were later transformed into constant 2004 pesos, using the annual inflation rate registered by the National Administrative Statistics Department (DANE). The average household head monthly income is significantly skewed, as by 2012 only district 14 registered an average monthly salary close to 5 million COP, 2.751 USD $^{9}$, while more than half of the city districts have average salaries per month less than 1 million COP, 556 USD (Figure 6).

\footnotetext{
9 The official average exchange rate in 2012 was 1 USD = $1.798,23$ COP as recorded by Banco de la República, Colombia's Central Bank.
} 


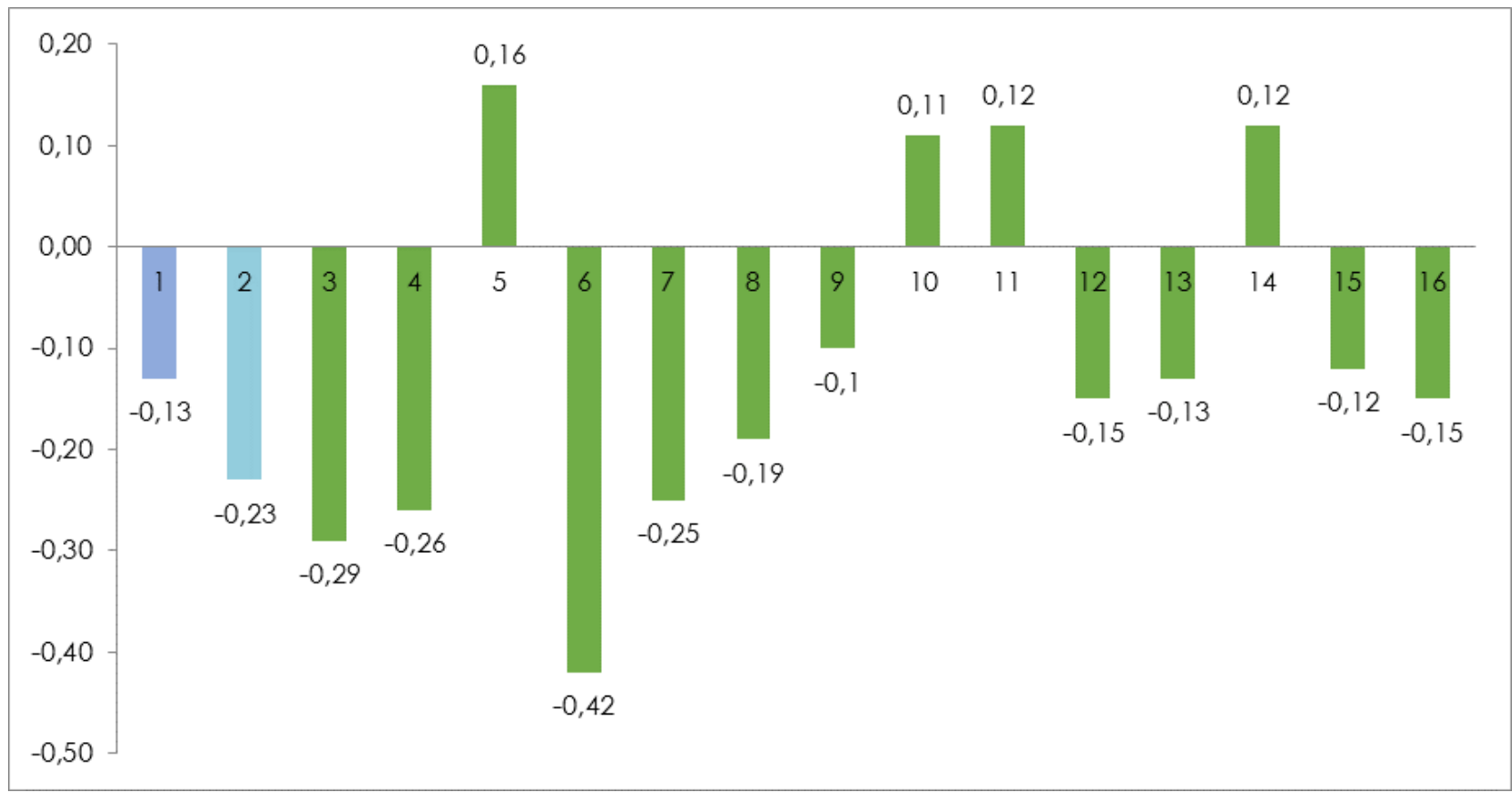

Figure 5. KSocial Scores per District 2011. Source: Hurtado et al. (2012).

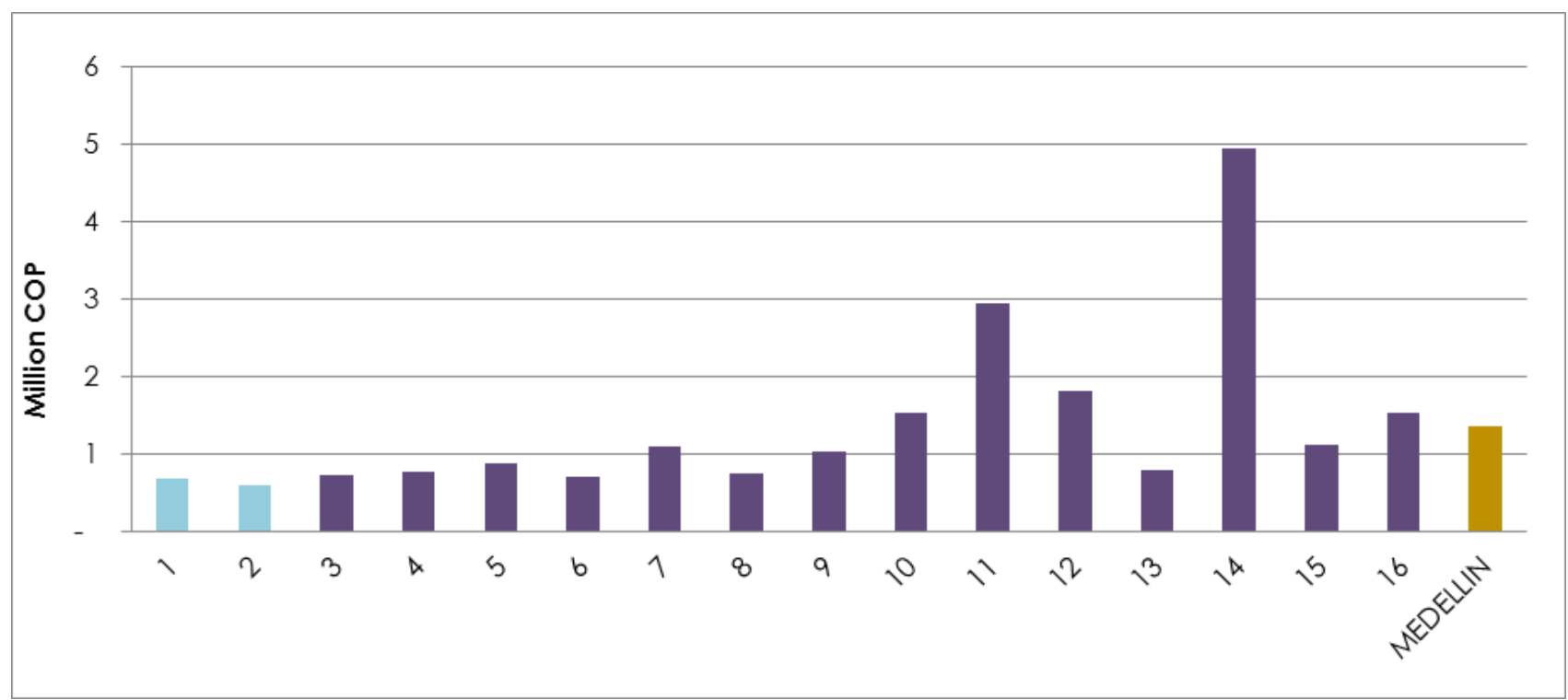

Figure 6. Average Household Head Monthly Income per District 2012. Source: Alcaldía de Medellín, $2013 a$.

Districts 1 and 2 are amongst the lowest average monthly household head income levels. An analysis of the average monthly income growth rate over the last decade shows that the trend of District 1 is close to that for the city as a whole, whereas District 2 is falling behind in relative terms. District 1 has benefitted from the extensive urban revitalisation program in recent years, unlike District 2 , so this result is in line with expectations.

\section{Results and Discussion}

Data limitations have meant that it has only been possible to replicate part of the Stanley et al. (2011a, 2011b) model, with variables that are proxies for those used in that model. Table 6 sets out the model estimated for risk of social exclusion.

There is a significant association between an increased number of trips and a reduced relative risk of social exclusion (where the trips measure included in the model only picks up trips of longer than 5 minutes or further than 5 blocks).

Table 6. Modelling risk of social exclusion and mobility.

\begin{tabular}{ll}
\hline Independent variables & $\begin{array}{l}\text { Standardised co-efficient } \\
\text { values (t-value) }\end{array}$ \\
\hline Social capital & $-0.287(-1.3)$ \\
Trips per day & $-0.787(-2.8)$ \\
Daily household head income & $0.12(0.4)$ \\
\hline
\end{tabular}


Recalling that each district has fewer than two trips, on average, per person per day, an increase of one trip is associated with a reduction of 0.787 in the risk of social exclusion, which is a much stronger impact than in the Australian modelling. The average number of trips in that Australian research was close to four per person per day, or about twice the number counted in the current paper. An increase of one trip per day is thus, in relative terms, much more significant than it is in the Australian study. With very short trips excluded in the Medellín study, the likelihood is that a significant proportion of increased trips (as measured) in that city will be for purposes such as employment or education. The high value underlines the importance of promoting mobility as a means of reducing risk of social exclusion, through initiatives such as Metrocable, in Medellín.

Social capital has a weak association with reduced risk of social exclusion, in the direction expected, such that measures to improve social capital will reduce risk of social exclusion. However, the social capital variable is only significant at the $22 \%$ level. However, significance was found to be much stronger in the Stanley et al. model. The different components of social capital measured between Stanley et al. and BARCAS could account for the different findings. Unlike BARCAS, the Australian study did not include measures of reciprocity in its modelling, as discussed previously. The specific questions asked, although nominally covering the same concept, showed variation in detail, also likely to account for some of the different outcomes.

The income variable was not at all significant in this model, which could be explained by the size of the informal economy and the resultant difficulties in developing a reasonable measure for household income. The model $R^{2}$ suggests that $58 \%$ of the variance in risk of social exclusion, as measured, is explained by the included variables but the key finding is the strong association between trips and risk of social exclusion.

The second part of the Stanley et al. (2011a, 2011b) modelling approach examined the relationship between risk of social exclusion, sense of community, various measures of psychological well-being and personal well-being. The current study was only able to examine the relationship between its measure of risk of social exclusion and quality of life, at District level. The resulting regression model showed a significant relationship between relative risk of social exclusion and selfperceived quality of life, the lower the risk of exclusion the higher the well-being level $\left(R^{2}=0.71\right.$; $t$-value on risk of social exclusion $=-5.8$; model significant at the 1 per cent level). Thus the Australian model of the association between social exclusion and well-being appears to be replicated in Medellín.

\section{Conclusions}

Metrocable was introduced in Medellín with a major aim of improving mobility opportunities for residents in areas characterised by significant disadvantage, with the desire to promote social inclusion. This study has developed measures of risk of social exclusion and found that Districts 1 and 2, served by Metrocable, are characterised by populations with a relatively high risk of social exclusion, compared to other parts of Medellín. The regression analysis undertaken for this study suggests that improving trip rates is likely to be one way to reduce the risk of social exclusion in districts with a relatively high risk of social exclusion and, in turn, improve the well-being of their inhabitants.

Motor cycle mode share is growing in the area of Line $\mathrm{K}$, with associated increases in accident numbers and costs. This trend, and the demand pressures on Metrocable, suggests a need for research to examine the extent to which Metrocable system expansion might deliver lower accident costs, through some mode switching from motor cycle to Metrocable.

This study was seeking to replicate modelling of the relationship between mobility, some other independent variables, and risk of social exclusion undertaken by Stanley et al. (2011a, 2011b). Their analysis collected purpose-specific primary data, whereas the present study could only rely on secondary data, seeking proxy measures. The scope of this study was thus, necessarily, constrained by the quality of the data available, which was limited and incomplete in many cases. The Medellín case study has suggested, however, that through careful selection of data, it should be possible to mirror the Stanley et al. (2011a, 2011b) modelling framework for wider application, using secondary data and thus a more cost and time effective form of evaluation. More importantly, this paper also contributes to the policy debate on how to reduce social exclusion in a developing economy. It has demonstrated the important role that improving mobility opportunities can play in reducing risk of exclusion and lost opportunities. We are not aware of previous research that has demonstrated this connection in a quantitative manner.

\section{Acknowledgements}

Professor Ivan Sarmiento, Universidad Nacional de Colombia

\section{Conflict of Interests}

The authors declare no conflict of interests.

\section{References}

Agudelo V. L., Mejía G. Á., Sarmiento O. I., \& Córdoba M. J. (2012). Las publicitadas bondades de los sistemas de cable en contraste con las realidades cotidianas de los usuarios. In J. D. Davila (Ed.), Mo- 
vilidad urbana y pobreza Aprendizajes de Medellín y Soacha, Colombia (pp. 97-108). Medellín: The Development Planning Unit UCL, Universidad Nacional de Colombia.

Alcaldía de Medellín (2005). Encuesta calidad de vida Medellín 2004. Medellín: Alcaldía de Medellín, Departamento Administrativo de Planeación.

Alcaldía de Medellín (2006). Encuesta calidad de vida Medellín 2005. Medellín: Alcaldía de Medellín, Departamento Administrativo de Planeación.

Alcaldía de Medellín (2007). Encuesta calidad de vida Medellín 2006. Medellín: Alcaldía de Medellín, Departamento Administrativo de Planeación.

Alcaldía de Medellín (2008). Encuesta calidad de vida Medellín 2007. Medellín: Alcaldía de Medellín, Departamento Administrativo de Planeación.

Alcaldía de Medellín (2009). Encuesta calidad de vida Medellín 2008. Medellín: Alcaldía de Medellín, Departamento Administrativo de Planeación.

Alcaldía de Medellín (2010). Encuesta calidad de vida Medellín 2009. Medellín: Alcaldía de Medellín, Departamento Administrativo de Planeación.

Alcaldía de Medellín (2012). Encuesta calidad de vida Medellín 2011. Medellín: Alcaldía de Medellín, Departamento Administrativo de Planeación.

Alcaldía de Medellín (2013a). Encuesta calidad de vida Medellín 2012. Medellín: Alcaldía de Medellín, Departamento Administrativo de Planeación.

Alcaldía de Medellín (2013b). Informe Anual de Accidentalidad 2012. Medellín: Alcaldía de Medellín, Secretaria de transportes y tránsito. Retrieved from http://www.Medellín.gov.co/transito/archivos/acci dentalidad/informe_anual_2012.pdf

Alcaldía de Medellín, Universidad Nacional, \& Área Metropolitana del Valle de Aburrá (2001). AMVA Encuesta Origen Destino Hogares y Estudios Complementarios 2000. Medellín: Área Metropolitana del Valle de Aburrá.

Alcaldía de Medellín, Universidad Nacional, \& Área Metropolitana del Valle de Aburrá (2006). AMVA Encuesta Origen Destino Hogares y Estudios Complementarios 2005. Medellín: Área Metropolitana del Valle de Aburrá.

Alcaldía de Medellín, Universidad Nacional, \& Área Metropolitana del Valle de Aburrá (2013). AMVA Encuesta Origen Destino Hogares y Estudios Complementarios 2012.Medellín: Área Metropolitana del Valle de Aburrá.

Arango Gómez, C., Velásquez Torres, J. M., \& Bocarejo Suescún, J. P. (2011). Impacto del sistema de cable aéreo (Metrocable) sobre la accesibilidad en la comuna \#1 de Medellín. Bogotá: Universidad de Los Andes.

Brand, P., \& Davila, J. (2011). Mobility innovation at the urban margins. City: Analysis of Urban Trends, Culture, Theory, Policy, Action, 15(6), 647-661.

Burchardt, T., LeGrand, J., \& Piachaud, D. (2002). De- grees of Exclusion: Developing a Dynamic, Multidimensional Measure. In J. Le Grand \& D. Piachaud (Eds.), Understanding Social Exclusion (pp. 30-43). Oxford: Oxford University Press.

Cao, N. Y., \& Sano, K. (2012). Estimating Capacity and Motorcycle Equivalent Units on Urban Roads in Hanoi, Vietnam. Journal of Transportation Engineering, 138, 776-785.

Coupé, F. (2012). Los Metrocables: Riesgo, pobreza e inclusion. In J. D. Davila (Ed.), Movilidad Urbana y Pobreza: Aprendizajes de Medellín y Soacha, Colombia (pp. 59-71). Medellín: The Development Planning Unit UCL, Universidad Nacional de Colombia.

Coupé, F., Brand, P., \& Dávila, J. D. (2012). Medellín: Contexto institucional y cambio de paradigma urbano. In J. D. Davila (Ed.), Movilidad Urbana y Pobreza: Aprendizajes de Medellín y Soacha, Colombia (pp. 47-58). Medellín: The Development Planning Unit UCL, Universidad Nacional de Colombia.

Coupé, F., \& Cardona, J.G. (2012). Impacto de los Metrocables en la economía local. In J. D. Davila (Ed.), Movilidad Urbana y Pobreza: Aprendizajes de Medellín y Soacha, Colombia (pp. 80-96). Medellín: The Development Planning Unit UCL, Universidad Nacional de Colombia.

Hurtado, D., García, D., \& Copete, A. F. (2012). La Tercera Medición del Capital Social en Colombia BARCAS 2011: Resultados Medición de Capital Social en Medellín. Fundación Antonio Restrepo Barco, Alcaldía de Medellín. Retrieved from http://www.funrestrepo barco.org.co/publicacion_1.php?\&id=12

International Wellbeing Group. (2006). Personal Wellbeing Index. Melbourne: Australian Centre on Quality of Life, Deakin University.

Jaramillo, C., Lizárraga, C., \& Grindlay, A. L. (2012). Spatial disparity in transport social needs and public transport provision in Santiago de Cali (Colombia). Journal of Transport Geography, 24, 340-357.

Kenyon, S., Lyons, G., \& Rafferty, J. (2002). Transport and social exclusion: Investigating the possibility of promoting inclusion through virtual mobility. Journal of Transport Geography, 10(3), 207-219.

Leibler, L., \& Brand, P. (2012). Movilidad e inclusion social: La experiencia desde la periferia de Medellín y el primer Metrocable. Bulletin de l' Institut Francais d'Etudes Andines, 41(3), 363-387.

Metro de Medellín (2004). Ejemplo de Intermodalidad: Sistema de Tranporte por Cable Aereo Integrado al Sistema Metro de Medellín. Medellín: Metro de Medellín.

Obst, P. L., \& White, K. M. (2004). Revisiting the sense of community index: A confirmatory factor analysis. Journal of Community Psychology, 32(6), 691-705.

Putnam, R. (1995). Bowling alone: America's declining social capital. Journal of Democracy, 6, 65-78.

Ryff, C. D. (1989). Happiness is everything, or is it? Explorations on the meaning of psychological well-being. 
Journal of Personality and Social Psychology, 57, 1069-1081.

Sarmiento, O. I., Córdoba, M. J., Mejía, G. Á., \& Agudelo, V. L. (2012). Metrocables y patrones de viaje en Medellín. Inclusión de variables latentes en los modelos de transporte. In J. D. Davila (Ed.), Movilidad Urbana y Pobreza: Aprendizajes de Medellín y Soacha, Colombia (pp. 72-79). Medellín: The Development Planning Unit UCL, Universidad Nacional de Colombia.

Sen, A. K. (2000). Social Exclusion: Concept, Application, and Scrutiny. Manila: Office of Environment and Social Development, Asian Development Bank.

Social Exclusion Unit. (2003). Making the Connections: Final report on Transport and Social Exclusion. Retrieved from http://www.socialexclusionunit.gov.uk/ publications/reports/html/transportfinal/summary

Spinney, J. E. L., Scott, D. M., \& Newbold, K. B. (2009). Transport mobility benefits and quality of life: A time perspective of elderly Canadians. Transport Policy, 16, 1-11.

Stanley, J., \& Lucas, K. (2008). Social exclusion: What can public transport offer? Research in Transportation Economics, 22(1), 36-40.
Stanley, J., \& Mulley, C. (2010). Workshop report: Social inclusion. Research in Transportation Economics, 29, 275-279.

Stanley, J., Hensher, D., Stanley, J. R., Currie, G., Greene, W., \& Vella-Brodrick, D. (2011a). Social Exclusion and the Value of Mobility. Journal of Transport Economics and Policy, 45, 197-222.

Stanley, J., Hensher, D., Stanley, J.R., \& Vella-Brodrick, D. (2011b). Mobility, social exclusion and well-being: Exploring the links. Transportation Research Part A, 45, 789-801.

Stanley, J. K., Stanley J. R., \& Hensher, D. (2012). Mobility, Social Capital and Sense of Community: What Value? Urban Studies, 49(16), 3595-3609.

Sudarsky, J. (1999). Colombia's Social Capital: The National Measurement with the BARCAS. Bogotá: National Planning Office.

Tobón Molina, M. P. (2012). Rentas Inmobiliarias Privadas en la Distribución de Cargas y Beneficios de los Proyectos Urbanos: Estudio del Polígono de la Estación Andalucía del Metrocable de Medellín. PhD Dissertation, Universidad Nacional de Colombia, Medellín.

\section{About the Authors}

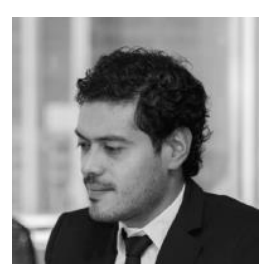

\section{Diego Zapata Cordoba}

Colombian economist with Master of Transport Management from the University of Sydney. Researcher on mobility related social exclusion and sustainable transport policies, currently working on the provision of a passenger information system and the assessment of a multidimensional level of service for bus passengers in Medellin, Colombia. Guest columnist in local newspapers on mobilityrelated matters.

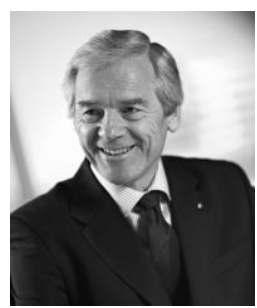

\section{John Stanley}

Professor John Stanley joined the Institute of Transport and Logistics Studies at University of Sydney in July 2008 as Adjunct Professor and Bus Industry Confederation Senior Research Fellow in Sustainable Land Transport. Prior to taking on this role, he had nine years as Executive Director of Bus Association Victoria, after eight years as Deputy Chairman of the National Road Transport Commission. He has published widely on transport policy and planning and was awarded an Australian Centenary Medal for services to public transport and conservation.

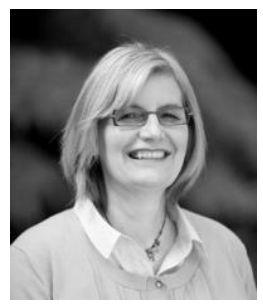

\section{Dr. Janet Stanley}

Dr. Janet Stanley is Chief Research Officer, and leads the doctoral program, at Monash Sustainability Institute, Monash University. She takes an inter-disciplinary approach to exploring the interface between social, economic and environmental sustainability at the policy and community levels. Janet maintains a high rate of publications in academic journals, book chapters and books, as well as being a past policy advisor for Australian federal and state governments. 